\title{
Development of Purification Method and Identification of a Peptide Antibiotic Produced by Lactococcus lactis IO-1
}

\author{
Hiromi Matsusaki, Naoyuki Endo, Kenji SonOmoto and Ayaaki IsHiZaKi* \\ Laboratory of Microbial Technology, Department of Food Science and Technology, Faculty of Agriculture, Kyushu University, 6-10-1, \\ Hakozaki, Higashi-ku, Fukuoka 812, Japan
}

Received November 27, 1995

\begin{abstract}
The culture supernatant of Lactococcus lactis IO-1, which was isolated in our laboratory, inhibited the cell growth of various Gram-positive bacteria but did not inhibit the nisin A-producing strain, L. lactis NCDO 497 . A nisin-like peptide antibiotic produced by $L$. lactis IO-1 was efficiently purified sequentially by acid treatment (at pH 3), ammonium sulfate precipitation, cation-exchange chromatography and reversed-phase high performance liquid chromatography. Dissociation of the peptide aggregates with high molar concentrations of urea resulted in successful purification. The molecular mass of this peptide antibiotic was 3335.67 by fast atom bombardment-mass spectrometry, confirming that the peptide antibiotic from $L$. lactis IO-1 is nisin $\mathrm{Z}$, a natural nisin variant. The purification method used is rapid, simple and effective, permitting the specific activity to increase 122-fold, and the recovery was $24 \%$.
\end{abstract}

Keywords: nisin, bacteriocin, Lactococcus lactis, lactic acid bacteria

Lactic acid bacteria are important in the food industry, in particular for the production of traditional fermented foods. They are responsible for the specific taste and texture that develop during the preparation by fermentation of various kinds of traditional foods. They produce a variety of antibacterial compounds such as organic acids, diacetyl and hydrogen peroxide. Some lactic acid bacteria produce bacteriocins, which are proteinaceous compounds that are generally able to inhibit the growth of closely related species (Klaenhammer, 1988). Some bacteriocins can also inhibit the growth of pathogens and spoilage organisms during the processing and fermentation of foods. It is anticipated that they will be used as natural food preservatives in the near future.

Nisin, or more precisely nisin A, is a bacteriocin that is produced by some strains of Lactococcus lactis. It is known as a peptide antibiotic (Mattick \& Hirsch, 1944, 1947; Hurst, 1981) and a lantibiotic such as epidermin (Allgaier et al., 1985) and Pep5 (Kellner et al., 1989). Nisin is heat stable at acidic $\mathrm{pH}$ and has antibacterial actions against a broad spectrum of Gram-positive bacteria. In view of its strong activity against clostridia and listeria which are food pathogens and the fact that it can be degraded in human alimentary canals, nisin $\mathrm{A}$ has been approved by the World Health Organization as a food preservative for use in the food industry. Nisin (nisin A), identified by Gross \& Morell (1971), is composed of 34 amino acids, which include unusual amino acids such as dehydroalanine, dehydrobutyrine, lanthionine and 3-methyllanthionine. Nisin is synthesized on ribosomes as a precursor peptide of 57 amino acids. It is subjected to various modifications, including cleavage of a leader peptide of 23 amino acids by posttranslational processing (Buchman et al., 1988; Kaletta \& Entian, 1989), which yield the final product, namely, active nisin. The genes involved in the biosynthesis of nisin have been cloned and sequenced (Engelke et al., 1992, 1994; Kuipers et al., 1993; van der Meer et al., 1993). However, the mechanism of the biosynthesis has not been satisfactorily characterized.

L. lactis IO-1 isolated in our laboratory has proved to be a quite unique and highly potent strain producing L-lactate from xylose as well as glucose (Ishizaki et al., 1992a, 1993). Furthermore, we developed useful systems for L-lactate fermentation by built-in electrodialysis with a microfilter module (Ishizaki et al., 1990a; Nomura et al., 1991; Vonktaveesuk et al., 1994). In the course of biochemical characterization and taxonomic study of strain IO-1, the strain was found to produce and secrete an antibacterial substance, presumably a nisin-like peptide antibiotic (Ishizaki et al., 1990b, 1990c, 1992b). Because formation of the dehydro residues and the thioether cross-linkages in nisin is due to stereospecific reactions by as yet unidentified enzymes, genetic analysis is only one of the approaches to the characterization of these peptides. Therefore, the structure of peptides such as nisin must be elucidated after their complete purification. In a previous report (Ishizaki et al., 1992b), we clarified the presence of dehydro residues in the peptide antibiotic from $L$. lactis $\mathrm{IO}-1$ and suggested that it might be a new derivative of nisin. Despite the results of the analysis of the purified peptide in the previous study, the structure of the peptide is still unclear because degradation and/or aggregation of the peptide might have taken place during the previous purification process.

In this paper, we describe an efficient purification of the peptide antibiotic from $L$. lactis IO-I with a high recovery. The structure of the peptide was also determined from the pure product obtained.

* To whom correspondence should be addressed. 


\section{Materials and Methods}

Bacterial strains and culture conditions The microorganism used for antibiotic production was L. lactis IO-1 (JCM 7638), which had been isolated in our laboratory (Ishizaki et al., 1990b). The indicator strain for assays of antibacterial activity was Bacillus subtilis $\mathrm{Cl}$, which was also isolated in our laboratory (Ishizaki et al., 1992c). For testing sensitivity to antibiotics, L. lactis NCDO 497 (nisin A producer), L. lactis JCM $5805^{\mathrm{T}}$ (nisin non-producer), L. lactis subsp. cremoris TUA 1344L, Enterococcus faecalis JCM $5803^{\mathrm{T}}$, Clostridium acetobutylicum IFO $13948^{\mathrm{T}}$, B. coagulans JCM $2257^{\mathrm{T}}$, B. stearothermophilus JCM $2501^{\mathrm{T}}$, B. subtilis C1 and Pseudomonas aeruginosa KYU-1 (our strain) were used. All lactic acid bacteria, $E$. faecalis and $C l$ acetobutylicum were grown in thioglycolate medium without glucose (TGC medium, Difco Laboratories, Detroit, Mich., USA) at $30^{\circ} \mathrm{C}$, but L. lactis IO-1, E. faecalis and $C$ l acetobutylicum were grown at $37^{\circ} \mathrm{C}$. Bacilli and Ps. aeruginosa were grown in bouillon medium that consisted of $0.7 \%$ meat extract, $1 \%$ polypeptone and $0.5 \% \mathrm{NaCl}$ at $30^{\circ} \mathrm{C}$, but $B$. coagulans at $37^{\circ} \mathrm{C}$.

Antibiotic production Unless otherwise noted, the antibiotic was produced as follows. The stock culture of strain IO-1 was subcultured in $10 \mathrm{ml}$ of TGC medium for 18 $\mathrm{h}$ in a static culture, which was then transferred to $100 \mathrm{ml}$ of the following medium, referred to as $\mathrm{CMG}$ medium. CMG medium contained $0.5 \%$ yeast extract, $0.5 \%$ polypeptone, $0.5 \%$ $\mathrm{NaCl}$ and $1 \%$ glucose in distilled water at $\mathrm{pH} 7.0$ for preculture. An aliquot of $30 \mathrm{ml}$ of the preculture, after growth at $37^{\circ} \mathrm{C}$ for $3 \mathrm{~h}$, was inoculated into a 5 -liter jar fermenter that contained 3 liters of CMG medium prepared with $3 \%$ glucose. The fermentation was carried out at $\mathrm{pH} 6.0$, maintained by a feeding system that supplied $5 \mathrm{~N} \mathrm{NaOH}$ at $37^{\circ} \mathrm{C}$ with agitation (400 rpm).

Bioassay For assays of antibacterial activity, growth inhibition of the indicator strain $B$. subtilis $\mathrm{Cl}$ was determined by turbidimetry as follows. An appropriate volume of the assay sample after acid treatment $(\mathrm{pH} 3.0)$ was added aseptically to $5 \mathrm{ml}$ of the assay medium (10-fold diluted CMG medium). The assay medium in each tube was then supplemented with an aliquot of a culture of the indicator strain that had been grown for $18 \mathrm{~h}$ with shaking ( 180 strokes $/ \mathrm{min}$ ) to give a cell concentration of approximately $10^{6}$ cells $/ \mathrm{ml}$, and the assay mixture was incubated at $30^{\circ} \mathrm{C}$ for $15 \mathrm{~h}$. Growth of the indicator strain was measured quantitatively as the absorbance at $562 \mathrm{~nm}$. One unit of activity of the antibiotic produced by $L$. lactis IO-1 is defined herein as an arbitrary unit (AU) of activity that is equivalent to the activity of $1 \mu \mathrm{g}$ of commercial nisin (ICN Biomedicals, Inc., Costa Mesa, Cal., USA; activity, 1,000 U/mg-solid; nisin content, 2.5\%). Determination of activity was performed in duplicate or more each time.

The antibacterial spectrum was obtained as follows. All anaerobic bacteria tested were grown for $24 \mathrm{~h}$ in static culture, and all aerobic bacteria were grown for $18 \mathrm{~h}$ with shaking (120 strokes/ $\mathrm{min}$ ). Each culture was inoculated into the assay medium (10-fold diluted $\mathrm{CMG}$ medium) to give a cell concentration of approximately $10^{6}$ cells $/ \mathrm{ml}$. A simple exception was the assay medium for $\mathrm{Cl}$. acetobutylicum, which was 10 -fold diluted RCM medium. RCM medium contained $0.3 \%$ yeast extract, $1.0 \%$ meat extract, $1.0 \%$ trypticase peptone (Becton Dickinson, Cockeysville, Md., USA), 0.5\% glucose, $0.5 \% \mathrm{NaCl}, 0.3 \%$ sodium acetate, $0.1 \%$ soluble starch and $0.05 \%$ L-cysteine hydrochloride $(\mathrm{pH} 6.8)$. The culture broth of L. lactis IO-1 was centrifuged at $16,000 \times \mathrm{g}$ for $30 \mathrm{~min}$ to pellet the cells. The $\mathrm{pH}$ of the supernatant was then adjusted to 3.0 with concentrated $\mathrm{HCl}$. After the supernatant had stood overnight at $4^{\circ} \mathrm{C}$, it was centrifuged at $16,000 \times g$ for $30 \mathrm{~min}$ to remove any precipitate that had formed. The resulting supernatant was aseptically added to the assay medium in each tube. After incubation at each optimal growth temperature for $18 \mathrm{~h}$, the minimum inhibitory concentration (MIC) of the culture supernatant from $L$. lactis IO- 1 was taken as the minimum effective volume of the supernatant per milliliter of the assay medium. The antibacterial activity of commercial nisin was taken as the control activity.

Separation of antibiotic The culture supernatant of $L$. lactis IO-1 from a jar fermenter was adjusted to $\mathrm{pH} 3.0$ with concentrated $\mathrm{HCl}$ and was allowed to stand overnight at $4^{\circ} \mathrm{C}$. After the precipitate formed was removed by centrifugation at $16,000 \times g$ for $30 \mathrm{~min}$, the active supernatant was brought to $70 \%$ saturation by the slow addition of solid ammonium sulfate and allowed to stand overnight at $4{ }^{\circ} \mathrm{C}$. The precipitate was collected by centrifugation at $16,000 \times \mathrm{g}$ for $30 \mathrm{~min}$ and then suspended in a small amount of $0.01 \mathrm{~N} \mathrm{HCl}$. This suspension was dialyzed against $8 \mathrm{M}$ urea- $\mathrm{HCl}(\mathrm{pH} 3.0)$ in a Spectra/Por membrane (Spectrum Medical Industries, Inc., Houston, Tex., USA; molecular weight cutoff, 1,000) to desalt the protein and disrupt any aggregates.

Cation-exchange chromatography Further purification of the antibiotic was carried out by cation-exchange chromatography on a column of CM-Sephadex C-25 (Pharmacia, Uppsala, Sweden; $5 \mathrm{~cm}$ i.d. $\times 20 \mathrm{~cm}$ ). The active dialysate was loaded on the column and washed with $20 \mathrm{~mm}$ acetate buffer $(\mathrm{pH} 3.6)$ at a flow rate of $1 \mathrm{ml} / \mathrm{min}$ for $100 \mathrm{~min}$. The column was subsequently eluted with a $0-1.2 \mathrm{M} \mathrm{NaCl}-20$ $\mathrm{mm}$ acetate buffer ( $\mathrm{pH} 3.6$ ), as a linear gradient, at a flow rate of $1 \mathrm{ml} / \mathrm{min}$. Absorbance was monitored at $210 \mathrm{~nm}$.

Reversed-phase high performance liquid chromatography The pooled active fractions obtained from the cationexchange column were loaded on a $\mathrm{tC}_{18}$ Sep-Pak cartridge (Waters, Milford, Mass., USA), and the column was washed with $0.05 \%$ trifluoroacetic acid (TFA). The fraction with antibacterial activity was eluted with $50 \%$ acetonitrile in $0.05 \%$ TFA, desalted and concentrated. The eluate was then lyophilized. The active material was then dissolved in a small quantity of $0.01 \mathrm{M} \mathrm{HCl}$. Further purification was performed by reversed-phase high performance liquid chromatography (HPLC) on an Asahipak ODP-50 column (Asahi Chemical Industry Co., Ltd., Tokyo). For the mobile phase, solvent A was $0.05 \%$ TFA in distilled water and solvent B was $0.05 \%$ TFA in $100 \%$ acetonitrile. For preparative purposes, a large column $(21.5 \mathrm{~mm}$ i.d. $\times 300 \mathrm{~mm})$ was used with a linear gradient of $30-35 \%$ solvent $B$ in solvent $A$ over the course of $50 \mathrm{~min}$ at a flow rate of $4 \mathrm{ml} / \mathrm{min}$. Analytical chromatography was performed on a smaller column $(6.0 \mathrm{~mm}$ i.d. $\times 250$ $\mathrm{mm}$ ) with a linear gradient of $26^{-}-34 \%$ solvent $\mathrm{B}$ in solvent $\mathrm{A}$ 
over the course of $40 \mathrm{~min}$ at a flow rate of $1 \mathrm{ml} / \mathrm{min}$. Absorbance was monitored at $210 \mathrm{~nm}$. Each fraction with antibacterial activity was lyophilized.

Tricine-sodium dodecyl sulfate-polyacrylamide gel electrophoresis Tricine-sodium dodecyl sulfatepolyacrylamide gel electrophoresis (Tricine-SDS-PAGE) was performed by the method of Schägger \& von Jagow (1987) in 16.5\% T-6\% C gels. T denotes the total percentage concentration of both monomers (acrylamide and bisacrylamide). $\mathrm{C}$ denotes the percentage concentration of the crosslinker relative to the total concentration $\mathrm{T}$. A molecular mass marker kit (MW-SDS-17; Sigma Chemical Company, St. Louis, Mo., USA) was used as a source of standard proteins. After electrophoresis, the gel was stained with $0.025 \%$ SERVA blue G (Serva, Heidelberg, Germany) in $10 \%$ acetic acid. The molecular mass of the antibiotic was estimated after calculation of relative mobilities and regression analysis.

Molecular mass determination The peptide antibiotic purified from strain IO-1 was dissolved in $0.01 \mathrm{~N} \mathrm{HCl}$. Molecular mass of the peptide was determined by fast atom bombardment-mass spectrometry (FAB-MS) with a mass spectrometer (JMS-SX102; JEOL, Tokyo) equipped with a JMA-DA 6000 data system (JEOL). Glycerol was used as the matrix.

\section{Results}

Production of a peptide antibiotic from L. lactis IO-I Figure 1 shows the time course of antibiotic production during the growth of $L$. lactis IO-1. The original culture supernatant $(\mathrm{pH}$ 6.0) had little antibacterial activity, but considerable activity became apparent when the $\mathrm{pH}$ was adjusted to 3.0 with concentrated $\mathrm{HCl}$. Antibacterial activity increased in almost direct proportion to the extent of cell growth. Antibacterial activity increased to a maximum at the early stationary phase of growth, after which there was a sharp decrease in activity. Such changes are a well known characteristic of bacteriocins including nisin (De Vuyst \& Vandamme, 1992) by lactic acid bacteria, and they are due to hydrolytic enzymes that are secreted. Consequently, for the purification

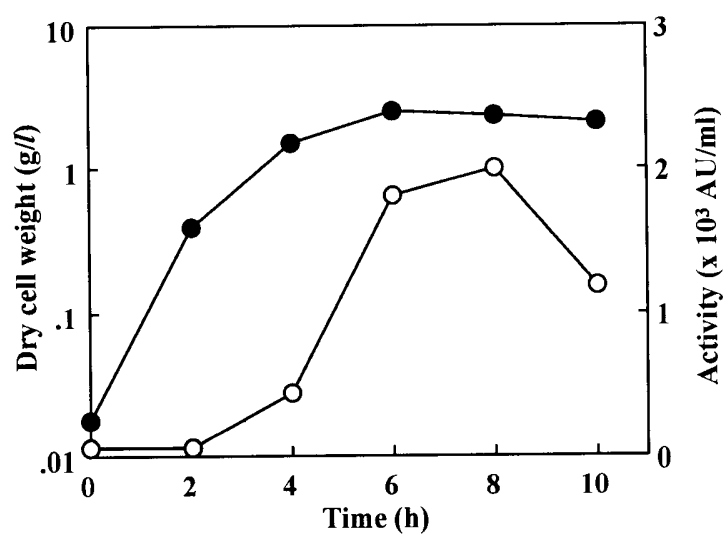

Fig. 1. Batch fermentation profile of L. lactis IO-1 microbial growth and antibiotic production. Testing run was performed in a 1 -liter jar fermenter with a working volume of $400 \mathrm{ml}$. The antibacterial activity of the supernatant ( $\mathrm{pH}$ 3.0) was determined after the precipitate formed by acid treatment of the culture supernatant ( $\mathrm{pH}$ 6.0) was removed by centrifugation. Symbols: $\bullet$, cell density measured in terms of absorbance at $562 \mathrm{~nm}$; , antibacterial activity $(\mathrm{AU} / \mathrm{ml})$. of the antibiotic, the culture supernatant was collected at the early stationary phase of growth.

Antibacterial spectrum The antibacterial spectrum of the antibiotic secreted in the culture broth of L. lactis IO-1 was determined and compared with that of commercial nisin. Table 1 indicates the MIC for the various strains tested. Both the culture supernatant from strain IO- 1 and commercial nisin inhibited not only the growth of closely related species which is generally characteristic of bacteriocins but also the growth of other Gram-positive bacteria tested. However, L. lactis NCDO 497, a nisin A producing strain, and L. lactis IO-1 were insensitive both to commercial nisin and to the culture supernatant from strain IO-1. This result indicates that antibiotic-producing strains were immune to their own products. In addition, these producing strains showed similar immunity to each of the antibiotics, namely, cross-immunity. Based on these results (Table 1), the antibiotic produced by strain $10-1$ was expected to be a nisin derivative.

Purification of the peptide antibiotic produced by $L$. lactis $1 O-1$ The peptide antibiotic produced by $L$. lactis IO- 1 , was partially purified by acid treatment, ammonium sulfate precipitation and cation-exchange chromatography. The activity of the supernatant after acid treatment was approximately 2,000 AU/ml (Table 2). Ammonium sulfate precipitation resulted in a 13 -fold increase in the specific activity with a recovery of approximately $80 \%$ of the activity. After dialysis, the active material was fractionated by cationexchange chromatography on a column of CM-Sephadex C-25 as described in Materials and Methods (Fig. 2). The fractions 84-96 with clear antibacterial activity were collected after the bioassay. Cation-exchange chromatography resulted in a 68-fold increase in the specific activity and recovery of activity was approximately $70 \%$ (Table 2 ).

When the active fractions from cation-exchange chromatography were analyzed by reversed-phase HPLC, four peaks were obtained as shown in Fig. 3. The four peak fractions, nos. 1, 2, 3 and 4 , had different antibacterial activities. The major peak fraction, no. 3 , was regarded as that

Table 1. Antibacterial spectrum of the culture supernatant from L. lactis IO- 1 and commercial nisin.

\begin{tabular}{|c|c|c|}
\hline \multirow[b]{2}{*}{ Strain } & \multicolumn{2}{|c|}{ Minimum inhibitory concentration (MIC) } \\
\hline & $\begin{array}{l}\text { Culture supernatant } \\
\qquad(\mu \mathrm{l} / \mathrm{ml})\end{array}$ & $\begin{array}{l}\text { Commercial nisin } \\
(\mu \mathrm{g} / \mathrm{ml})\end{array}$ \\
\hline $\begin{array}{l}\text { L. lactis subsp. lactis JCM } \\
5805^{\mathrm{T}}\end{array}$ & 35 & 10 \\
\hline $\begin{array}{l}\text { L. lactis subsp. cremoris TUA } \\
\text { 1344L }\end{array}$ & 60 & 50 \\
\hline E. faecalis $\mathrm{JCM} 5803^{\mathrm{T}}$ & 50 & 10 \\
\hline $\begin{array}{l}\text { Cl. acetobutylicum IFO } \\
13948^{\mathrm{T}}\end{array}$ & 10 & 10 \\
\hline B. coagulans JCM $2257^{\top}$ & 5 & 5 \\
\hline $\begin{array}{l}\text { B. stearothermophilus JCM } \\
250 \mathrm{I}^{\mathrm{T}}\end{array}$ & $<2.5$ & $<2.5$ \\
\hline B. subtilis $\mathrm{Cl}$ & 20 & 10 \\
\hline Ps. aeruginosa $\mathrm{K} Y \mathrm{U}-1$ & $>100$ & $>100$ \\
\hline L. lactis NCDO 497 & $>100$ & $>100$ \\
\hline L. lactis $\mathrm{IO}-1$ & $>100$ & $>100$ \\
\hline
\end{tabular}

Activity of the commercial nisin (nisin content $2.5 \%$ ) used was 1,000 units $/ \mathrm{mg}$. JCM, Japan Collection of Microorganisms; TUA, Tokyo University of Agriculture, Japan, IFO, Institute for Fermentation, Osaka, Japan; NCDO, National Collection of Dairy Organisms, Reading, England. 
Table 2. Purification of the peptide antibiotic produced by L. lactis IO-1.

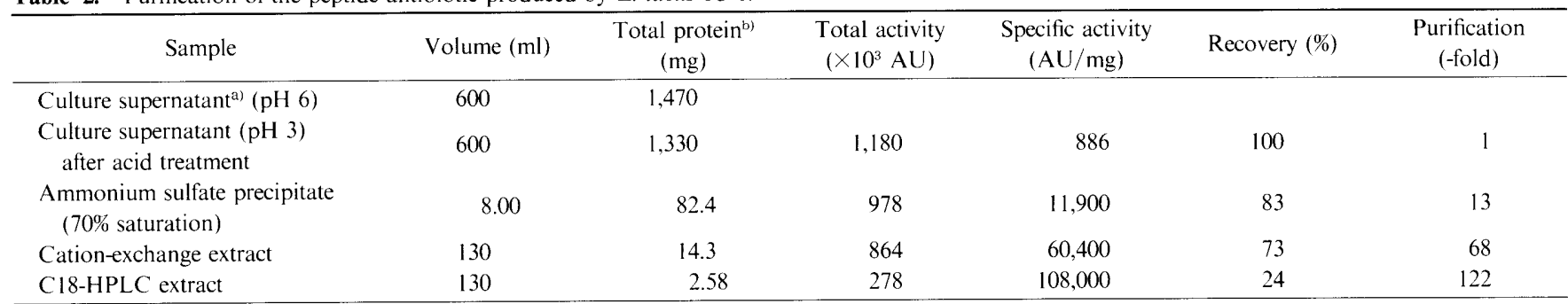

a) Culture supernatant was obtained from the culture broth of L. lactis IO-1 after $13 \mathrm{~h}$ cultivation as described in Materials and Methods.

b) Protein was estimated by the method of Lowry et al. (1951).

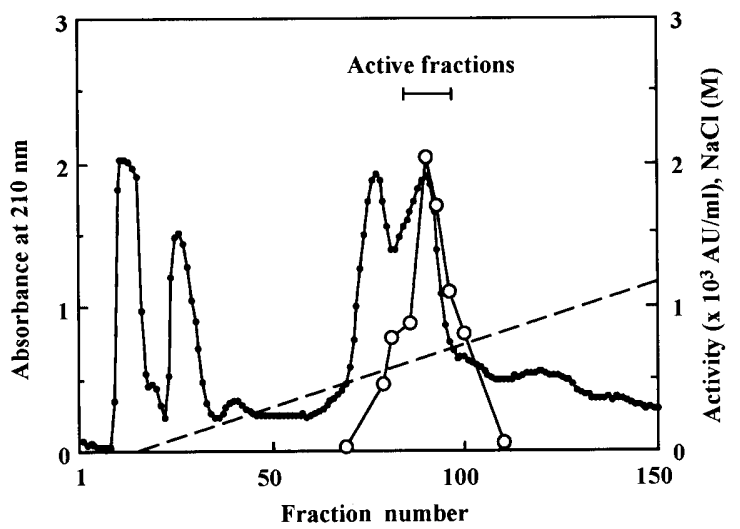

Fig. 2. Purification of the antibiotic by cation-exchange chromatography. Symbols: - absorbance at $210 \mathrm{~nm} ; 0$, antibacterial activity $(\mathrm{AU} / \mathrm{ml})$; ---$\mathrm{NaCl}$ gradient. Fractions 84-96, indicated by the bar, were collected for further purification.

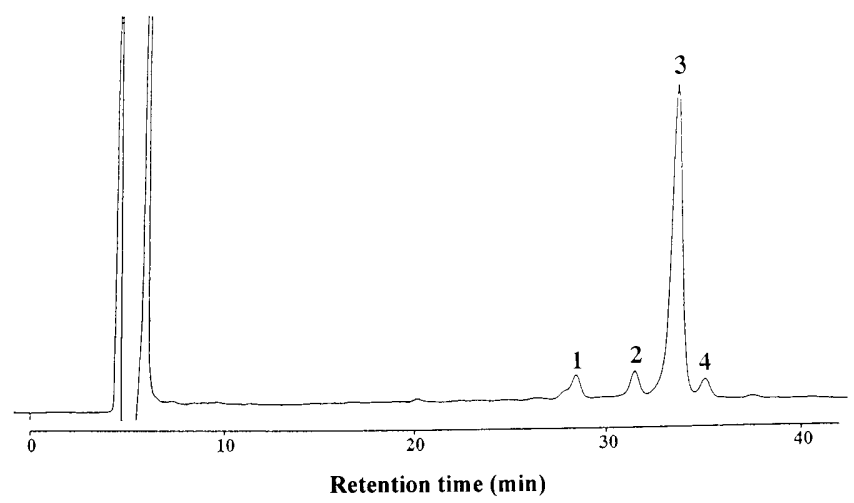

Fig. 3. Analysis by reversed-phase HPLC of the crude antibiotic. The crude antibiotic obtained by cation-exchange chromatography was subjected to HPLC. Peaks nos. 1, 2, 3 and 4 with different antibacterial activities were detected.

of the desired antibiotic produced by $L$. lactis IO-1. It included approximately $70 \%$ of the activity in the total eluate. The specific absorbance of the peptide at $210 \mathrm{~nm}$ was $33 \mathrm{mg}^{-1}$ $\mathrm{ml} \mathrm{cm} \mathrm{cm}^{-1}$. Because the other peaks, nos. 1, 2 and 4, had low activity and were also found in the analysis of the original culture supernatant, they were probably not generated by degradation of the mature peptide during our purification process.

The purity of the antibiotic was assessed by Tricine-SDSPAGE. The peak fraction no. 3, obtained by HPLC, was concentrated with $\mathrm{tC}_{18}$ Sep-Pak cartridge. After lyophilization and dissolution in a small quantity of $0.01 \mathrm{~N} \mathrm{HCl}$, the

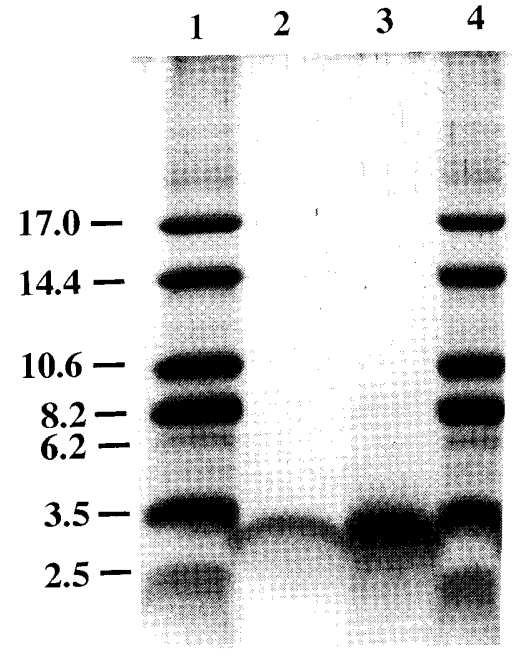

Fig. 4. Tricine-SDS-PAGE of the purified antibiotic. Lanes: 1, 4, lowmolecular-mass standards (kDa); 2 , peak fraction no. 3 obtained by HPLC; 3 , commercial nisin.

active material was subjected to Tricine-SDS-PAGE. A single band was detected on the gel, and the molecular mass of the peptide was estimated to be approximately $3.4 \mathrm{kDa}$ (Fig. 4). Analysis by Tricine-SDS-PAGE indicated that the molecular mass of the peptide antibiotic from strain IO-1 was almost the same as that of commercial nisin, namely, nisin A.

Molecular mass determination by mass spectrometry After HPLC, four peaks were detected and peak fraction no. 3 was regarded as the peptide of interest (Fig. 3). Amino acid composition and sequence analysis, ${ }^{1} \mathrm{H}-\mathrm{NMR}$ analysis (data not shown) as well as the deduced amino acid sequence of the precursor peptide (Araya et al., 1992) suggested that the peptide antibiotic produced by $L$. lactis IO-1 differed from nisin $\mathrm{A}$ in a single amino acid residue at position 27 (histidine in nisin $\mathrm{A}$ is replaced by asparagine in this peptide). Furthermore, we confirmed a significant difference in molecular mass between this peptide antibiotic and nisin $\mathrm{A}$ by FAB-MS (Fig. 5). The molecular mass of the peptide (peak fraction no. 3) purified from strain IO-1 was 3335.67 under the measurement conditions described in Materials and Methods and corresponding to the replacement of the single amino acid residue in nisin A (molecular mass, 3358.67 under the same measurement conditions). These results showed that the peptide of strain IO-1 was deduced to be nisin Z, a natural nisin variant, reported previously (Mulders et al., 1991). 


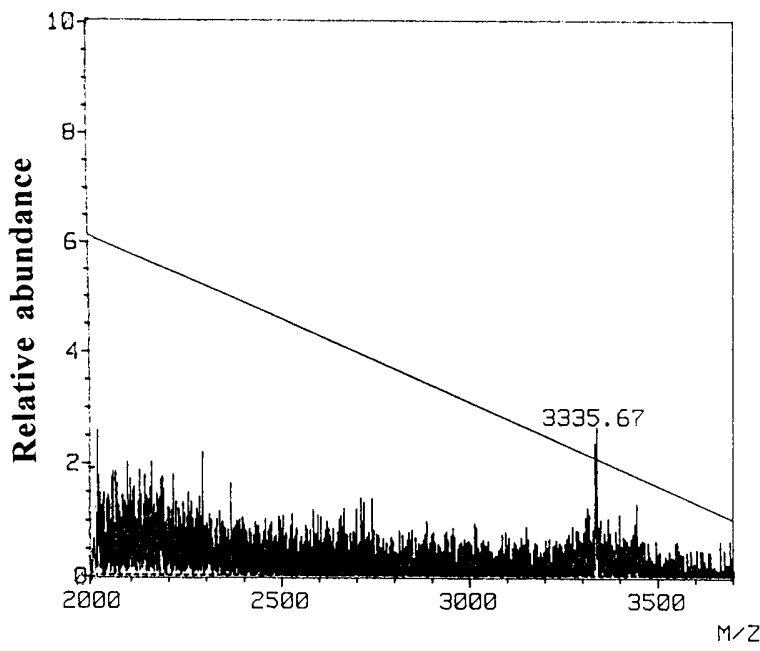

Fig. 5. FAB-MS spectrum of the peptide antibiotic purified from L. lactis IO-1.

\section{Discussion}

In this paper, the peptide antibiotic was efficiently purified, resulting in a product whose specific activity and recovery were a 122 -fold increase and $24 \%$, respectively (Table 2 ). This successful result is primarily caused by the solution to the following problem in the purification of bacteriocins.

Bacteriocins and nisin easily aggregate (Jarvis et al., 1968; Mфrtvedt et al., 1991; Muriana \& Klaenhammer, 1991; Piard et al. 1992). After ammonium sulfate precipitation of the culture supernatant from strain IO-1, the antibacterial activity was eluted in void fractions during gel filtration chromatography on a column of Sephadex G-25 (1,000-5,000 Da, Pharmacia) or G-50 (1,500-30,000 Da, Pharmacia), as a result of the aggregation of the peptide antibiotic with proteins. This phenomenon is probably the cause of the confusing analytical data that were used for the putative identification of the peptide in our previous report (Ishizaki et al., 1992b). An eight molar concentration of urea was used to solve this problem. No inactivation of the peptide antibiotic was observed when the ammonium sulfate precipitate was dialyzed against $8 \mathrm{M}$ urea- $\mathrm{HCl}(\mathrm{pH} 3.0)$. Fractionation of the active substance by cation-exchange chromatography without urea was unsuccessful, and the recovery was very low (data not shown).

Aggregates of bacteriocins reveal low activity and are often dissociated during purification to an active component, i.e., a monomer (Barefoot \& Klaenhammer, 1983; Mфrtvedt et al., 1991; Piard et al., 1992; Rodriguez et al., 1995). Thus, the apparent recovery yield increases to over $100 \%$. Because the activity levels of bacteriocins are affected by the chromatographic conditions and the culture media used, it is difficult to evaluate the final recovery obtained in comparison with other purification methods published.

The structure of the peptide antibiotic obtained in this study conforms with that of nisin $\mathrm{Z}$, a natural nisin variant, recently identified (Mulders et al., 1991) by its gene sequence (Araya et al., 1992), FAB-MS (Fig. 5), amino acid composition and sequence, and ${ }^{1} \mathrm{H}-\mathrm{NMR}$ (data not shown). Although Mulders et al. (1991) purified nisin Z by hydrophobic interaction chromatography and reversed-phase HPLC, specific activity and recovery of the activity were not described in this literature source. We obtained a nisin-like peptide antibiotic with high recovery $(24 \%)$ by a simple and rapid procedure. It is expected that this peptide should be more soluble than nisin $\mathrm{A}$ above $\mathrm{pH} 6$ because the asparagine side chain is more polar than the histidine side chain; furthermore, it has also a broad antibacterial spectrum as shown in Table 1. These facts suggest that this peptide could be used as a food preservative instead of nisin $\mathrm{A}$. This will require a more detailed characterization of the nisin variant. The purification method described in this paper will serve to initiate investigation of it.

Acknowledgments We thank M. Hayashi, K. Kinoshita, H. Oka, and K. Ogawa, Asahi Chemical Industry, Co., Ltd. for their kind support in the structure analysis of the peptide antibiotic from L. lactis IO-1. This work was supported in part by a Grant-in-Aid for Research from the Ministry of Education, Science and Culture, Japan.

\section{References}

Allgaier, H., Jung, G., Werner, R.G., Schneider, U. and Zähner, H (1985). Elucidation of the structure of epidermin, a ribosomally synthesized, tetracyclic heterodetic polypeptide antibiotic. Angew. Chem. Int. Ed. Engl., 24, 1051-1053.

Araya, T., Ishibashi, N. and Shimamura, S. (1992). Genetic evidence that Lactococcus lactis JCM7638 produces a mutated form of nisin. J. Gen. Appl. Microbiol., 38, 271-278.

Barefoot, S.F. and Klaenhammer, T.R. (1983). Detection and activity of lactacin B, a bacteriocin produced by Lactobacillus acidophilus. Appl. Environ. Microbiol., 45, 1808-1815.

Buchman, G.W., Banerjee, S. and Hansen, J.N. (1988). Structure, expression, and evolution of a gene encoding the precursor nisin, a small protein antibiotic. J. Biol. Chem., 263, 16260-16266.

De Vuyst, L. and Vandamme, E.J. (1992). Influence of the carbon source on nisin production in Lactococcus lactis subsp. lactis batch fermentations. J. Gen. Microbiol., 138, 571-578.

Engelke, G., Gutowski-Eckel, Z., Hammelmann, M. and Entian, K.-D (1992). Biosynthesis of the lantibiotic nisin: Genomic organization and membrane localization of the NisB protein. Appl. Environ. Microbiol., 58, 3730-3743.

Engelke, G., Gutowski-Eckel, Z., Kiesau, P., Siegers, K., Hammelmann, M. and Entian, K.-D. (1994). Regulation of nisin biosynthesis and immunity in Lactococcus lactis 6F3. Appl. Environ. Microbiol., 60, $814-825$.

Gross, E. and Morell, J.L. (1971). The structure of nisin. J. Am. Chem. Soc., 93, 4634-4635

Hurst, A. (1981). Nisin. Adv. Appl. Microbiol., 27, 85-123.

Ishizaki, A., Nomura, Y. and Iwahara, M. (1990a). Built-in electrodialysis batch culture, a new approach to release of end product inhibition. J. Ferment. Bioeng., 70, 108-113.

Ishizaki, A., Osajima, K., Nakamura, K., Kimura, K., Hara, T. and Ezaki, T. (1990b). Biochemical characterization of Lactococcus lactis IO-1 whose optimal temperature is as high as $37^{\circ} \mathrm{C}$. J. Gen. Appl. Microbiol., 36, 1-6.

Ishizaki, A., Hara, T. and Ezaki, T. (1990c). Lactococcus lactis IO-1 (JCM 7638), A new strain of homofermentative L-lactate producing coccus. In "5th European Congress on Biotechnology. Proceedings," Vol. 1, ed. by C. Christiansen, L. Munck and J. Villadsen. Nørharven A/S, Viborg, pp. 306-309.

Ishizaki, A., Ueda, T., Tanaka, K., and Stanbury, P.F. (1992a). L-Lactate production from xylose employing Lactococcus lacti IO-1. Biotechnol. Lett., 14, 599-604.

Ishizaki, A., Matsusaki, H., Uryu, K., Inui, T., Kurematsu, K., Ichii, S., Hayami, T., Tonokawa, M. and Koba, Y. (1992b). Biochemical properties of a new lantibiotic produced by Lactococcus lactis IO-1. J. Fac. Agric., Kyushu Univ., 37, 1-11.

Ishizaki, A., Tamura, M., Kimura, K., Koba, Y., Tonokawa, M. and Ezaki, T. (1992c). Characterization of newly isolated Bacillus 
subtilis $\mathrm{C} 1$ which is sensitive to antibiotic produced by lactic acid coccus. J. Ferment. Bioeng., 74, 248-250.

Ishizaki, A., Ueda, T., Tanaka, K. and Stanbury, P.F. (1993). The kinetics of end-product inhibition of L-lactate production from xylose and glucose by Lactococcus lactis IO-1. Biotechnol. Lett., 15, 489-494.

Jarvis, B., Jeffcoat, J. and Cheeseman, G.C. (1968). Molecular weight distribution of nisin. Biochim. Biophys. Acta, 168, 153-155.

Kaletta, C. and Entian, K.-D. (1989). Nisin, a peptide antibiotic: cloning and sequencing of the nis $A$ gene and posttranslational processing of its peptide product. J. Bacteriol., 171, 1597-1601.

Kellner, R., Jung, G., Josten, M., Kaletta, C., Entian, K.-D. and Sahl, H.-G. (1989). Pep5: Structure elucidation of a large lantibiotic. Angew. Chem. Int. Ed. Engl., 28, 616-619.

Klaenhammer, T.R. (1988). Bacteriocins of lactic acid bacteria. Biochimie, 70, 337-349.

Kuipers, O.P., Beerthuyzen, M.M., Siezen, R.J. and de Vos, W.M (1993). Characterization of the nisin gene cluster nis ABTCIPR of Lactococcus lactis. Requirement of expression of the nis $A$ and nisI genes for development of immunity. Eur. J. Biochem., 216, 281-291.

Lowry, O.H., Rosebrough, N.J., Farr, A.L. and Randall, R.J. (1951). Protein measurement with the Folin phenol reagent. J. Biol. Chem., 193, 265-275.

Mattick, A.T.R. and Hirsch A. (1944). A powerful inhibitory substance produced by group $\mathrm{N}$ streptococci. Nature, 154, 551.

Mattick, A.T.R. and Hirsch, A. (1947). Further observations on an inhibitory substance (nisin) from lactic streptococci. Lancet, ii, 512.

Mørtvedt, C.I., Nissen-Meyer, J., Sletten, K. and Nes, I.F. (1991). Purification and amino acid sequence of lactocin S, a bacteriocin produced by Lactobacillus sake L45. Appl. Environ. Microbiol., 57, 1829-1834.
Mulders, J.W.M., Boerrigter, I.J., Rollema, H.S., Siezen, R.J. and de Vos, W.M. (1991). Identification and characterization of the lantibiotic nisin Z, a natural nisin variant. Eur. J. Biochem., 201, 581-584.

Muriana, P.M. and Klaenhammer, T.R. (1991). Purification and partial characterization of lactacin $\mathrm{F}$, a bacteriocin produced by Lactobacillus acidophilus 11088. Appl. Environ. Microbiol., 57, 114121.

Nomura, Y., Yamamoto, K. and Ishizaki, A. (1991). Factors affecting lactic acid production, an approach to high speed batch culture. $J$. Ferment. Bioeng., 71, 450-452.

Piard, J.C., Muriana, P.M., Desmazeaud, M.J. and Klaenhammer, T. R. (1992). Purification and partial characterization of lacticin 481, a lanthionine-containing bacteriocin produced by Lactococcus lactis subsp. lactis CNRZ 481. Appl. Environ. Microbiol, 58, 279-284.

Rodriguez, J.M., Cintas, L.M., Casaus, P., Horn, N., Dodd, H.M., Hernandez, P.E. and Gasson, M.J. (1995). Isolation of nisinproducing Lactococcus lactis strains from dry fermented sausages. $J$. Appl. Bacteriol., 78, 109-115.

Schägger, H. and von Jagow, G. (1987). Tricine-sodium dodecyl sulfate-polyacrylamide gel electrophoresis for the separation of proteins in the range from 1 to $100 \mathrm{kDa}$. Anal. Biochem., 166, 368 379.

van der Meer, J.R., Polman, J., Beerthuyzen, M.M., Siezen, R.J., Kuipers, O.P. and de Vos, W.M. (1993). Characterization of the Lactococcus lactis nisin A operon genes nisP, encoding a subtilisinlike serine protease involved in precursor processing, and nisR, encoding a regulatory protein involved in nisin biosynthesis. $J$. Bacteriol., 175, 2578-2588.

Vonktaveesuk, P., Tonokawa, M. and Ishizaki, A. (1994). Stimulation of the rate of L-lactate fermentation using Lactococcus lactis IO-1 by periodic electrodialysis. J. Ferment. Bioeng., 77, 508-512. 